\title{
Soil Organic Carbon and Nutrients along an Alpine Grassland Transect across Northern Tibet
}

\author{
CAO Ying-zi',2, WANG Xiao-dan',*, LU Xu-yang1, YAN Yan', FAN Ji-hui ${ }^{1}$ \\ 1 Institute of Mountain Hazards \& Environment, Chinese Academy of Sciences, Chengdu 610041, China \\ 2 Graduate University of Chinese Academy of Sciences, Beijing 10oo49, China \\ *Corresponding author,e-mail: wxd@imde.ac.cn; First author, e-mail: Cherry880427@126.com
}

(C) Science Press and Institute of Mountain Hazards and Environment, CAS and Springer-Verlag Berlin Heidelberg 2013

\begin{abstract}
Soil carbon and nutrient contents and their importance in advancing our understanding of biogeochemical cycling in terrestrial ecosystem, has motivated ecologists to find their spatial patterns in various geographical area. Few studies have focused on changes in the physical and chemical properties of soils at high altitudes. Our aim was to identify the spatial distribution of soil physical and chemical properties in cold and arid climatic region. We also tried to explore relationship between soil organic carbon (SOC) and total nitrogen (TN), total phosphorus (TP), available nitrogen (AN), available phosphorus (AP), soil particle size distribution (PSD). Samples were collected at 44 sites along a $300 \mathrm{~km}$ transect across the alpine grassland of northern Tibet. The study results showed that grassland type was the main factor influencing SOC, TN and TP distribution along the Gangdise Mountain-Shenzha-Shuanghu Transect. SOC, TN and TP contents were significantly higher in alpine meadow than alpine steppe ecosystems. SOC, TN, TP and AN contents in two soil layers $(0-15 \mathrm{~cm}$ and $15-30 \mathrm{~cm})$ showed no significant differences, while AP content in top soil $(0-15 \mathrm{~cm})$ was significantly higher than that in sub-top soil (15-30 $\mathrm{cm})$. SOC content was correlated positively with TN and TP content ( $r=0.901$ and 0.510 , respectively). No correlations were detected for clay content and fractal dimension of particle size distribution (D). Our study results indicated the effects of vegetation on soil $\mathrm{C}, \mathrm{N}$ and $\mathrm{P}$ seem to be more important than that of rocks itself along latitude gradient on the northern Tibetan Plateau. However, we did not found similar impacts of vegetation on soil properties in depth. In
\end{abstract}

Received: 3 June 2012

Accepted: 20 March 2013 addition, this study also provided an interesting contribution to the global data pool on soil carbon stocks.

Keywords: Soil organic carbon; Total nitrogen; Total phosphorus; Particle size distribution; Alpine grassland; Tibet

\section{Introduction}

The terrestrial ecosystem C pool is about twice that in the atmosphere and nearly three times that in aboveground biomass (Eswaran et al. 1993; Heimann and Reichstein 2008), which plays an important role in global carbon cycle. Small changes in terrestrial ecosystem $\mathrm{C}$ pools will have significant effects on global $\mathrm{C}$ balance and climate change. The complicated nature of the sub-surface layer and disturbance by human activities make the terrestrial ecosystem one of the most unstable ecosystems (Piao et al. 2011). Alpine steppe and meadow are the dominant grassland types in northern Tibet, which cover a combined $94.4 \%$ of the total land area in this region(Gao et al. 2009a). The alpine grassland ecosystem is extremely sensitive to environmental changes on the northern Tibetan Plateau due to arid and cool climate.

Soil $\mathrm{C}$ storage in grasslands is affected by many factors, including land management(BatlleBayer et al. 2010; Preger et al. 2010; Wang et al. 2011) and climate change (Johnson et al. 2011; Xu et al. 2011). $\mathrm{N}$ deposition can affect significantly $\mathrm{C}$ 
cycle by directly enhancing plant growth and net primary productivity (Bai et al. 2008; Magill et al. 1997) and reduces the rates of organic matter decomposition in sediment (Hobbie 2008). Varying responses of soil $\mathrm{C}$ stocks to $\mathrm{N}$ addition have been reported. For example, in a grassland field experiment, high $\mathrm{N}$ input $\left(4 \mathrm{~g} \mathrm{~m}^{-2} \mathrm{yr}^{-1}\right)$ promoted some plant species produced lignin-rich litter and increased stabilisation of soil C (Dijkstra et al. 2004). A study in a prairie ecosystem showed that $\mathrm{N}$ fertilisation $\left(10 \mathrm{~g} \mathrm{~m}^{-2} \mathrm{yr}^{-1}\right)$ can significantly increase soil C sequestration (Wilson et al. 2009). However, other studies have shown that the effect of $\mathrm{N}$ deposition on $\mathrm{C}$ sequestration in grasslands is negligible and that other factors, such as water availability, may be more important (Lu et al. 2011; Mack et al. 2004; Wamelink et al. 2009). Therefore, the effects of nitrogen deposition on grassland ecosystem carbon storage remain controversial.

Previous studies have shown that the $\mathrm{P}$ release from rock weathering is a major factor governing the accumulation of organic matter and plays an important role in soil $\mathrm{C}$ turnover (Hamdan et al. 2012). When $P$ availability is limited, $C$ turnover is inhibited because microbial biomass becomes less efficient in utilising substrates (Saggar et al. 2000). Immobilisation of $\mathrm{P}$ by microbes provides a $\mathrm{P}$ conservation mechanism in soils with fluctuating redox potential and may ultimately stimulate more $\mathrm{C}$ cycling in ecosystems (Liptzin and Silver 2009). Soil $\mathrm{C}$ will also affect the storage of $\mathrm{P}$ in some soils. In soil erosion by water, soil carbohydrates play a role in determining how extensively $\mathrm{P}$ is exposed to overland flow (McDowell and Sharpley 2003). However, the exact relationship between $P$ deposition and soil organic carbon (SOC) storage in alpine grassland ecosystems is still unknown.

Northern Tibet is located between the Gangdise and the northern part of the Nyainqentanglha mountain ranges. The average elevation of this region is over 4,500 $\mathrm{m}$ a.s.l. (Gao et al. 2009a; 2009b). Most studies on the effect of increasing available $\mathrm{N}$ on $\mathrm{C}$ sequestration have been carried out in low latitude ecosystems. A few studies have documented the relationships of soil total nitrogen (TN) and soil total phosphorus (TP) with $\mathrm{C}$ storage in alpine grassland ecosystems. Therefore, we established a $300 \mathrm{~km}$ latitudinal transect through northern Tibet and used this transect to compare $\mathrm{SOC}, \mathrm{TN}, \mathrm{TP}$ and fractal dimension of PSD along latitude gradients. In this paper, our aims are to (i) characterize the spatial distribution of soil physical and chemical properties along the latitude gradient; (ii) explore relationship between soil characteristics and SOC content; and (iii) identify key factors determining SOC content in alpine grassland ecosystems.

\section{Material and Methods}

\subsection{Study area}

The study area focuses on a $300 \mathrm{~km}$ south to north transect in northern Tibet. The Gangdise Mountains-Shenzha-Shuanghu Transect (GSST) extends from $30.42^{\circ} \mathrm{N}$ to $33.15^{\circ} \mathrm{N}$ and $88.68^{\circ} \mathrm{E}$ to $89.45^{\circ} \mathrm{E}$ (Figure 1). The average elevation of the region is more than $4,500 \mathrm{~m}$ a.s.l. with high altitudes in both the south and north and a low altitude in the middle. The climate of northern Tibet is predominantly cold and dry, with an annual average temperature of $-2.8-1.6^{\circ} \mathrm{C}$ (Liu et al. 2003). Under the influences of atmospheric circulation and terrain, rainfall along the transect varies from nearly $300 \mathrm{~mm}$ in the south to less than $200 \mathrm{~mm}$ in the north. The high-altitude western wind currents are strong in the winter and spring, and gales above Grade 7 are frequent (sometimes, the wind force is as high as Grade 1012), which results in dry weather and low soil temperature (Liu et al. 2003). Vegetation varies gradually from alpine meadows in the south to alpine steppes in the north (Figure 2). The distribution of grassland types is almost completely determined by the climatic gradients, especially by precipitation( $\mathrm{Ni}$ and Zhang 2000). The alpine meadows are mostly in the Gangdise Mountains and are dominated by Koresia pygmaea C. B. Clarke. Alpine steppes occupy the northern portion of the GSST and are dominated by Stipa purpurea Griseb (Li 2000; Yang et al. 2010). Grassland degradation due to historic overgrazing is one of main eco-environmental problems in this area (Wang et al. 2012).

\subsection{Soil sampling}

Field work took place at the end of August and early September 2010 along the 300-km transect. 


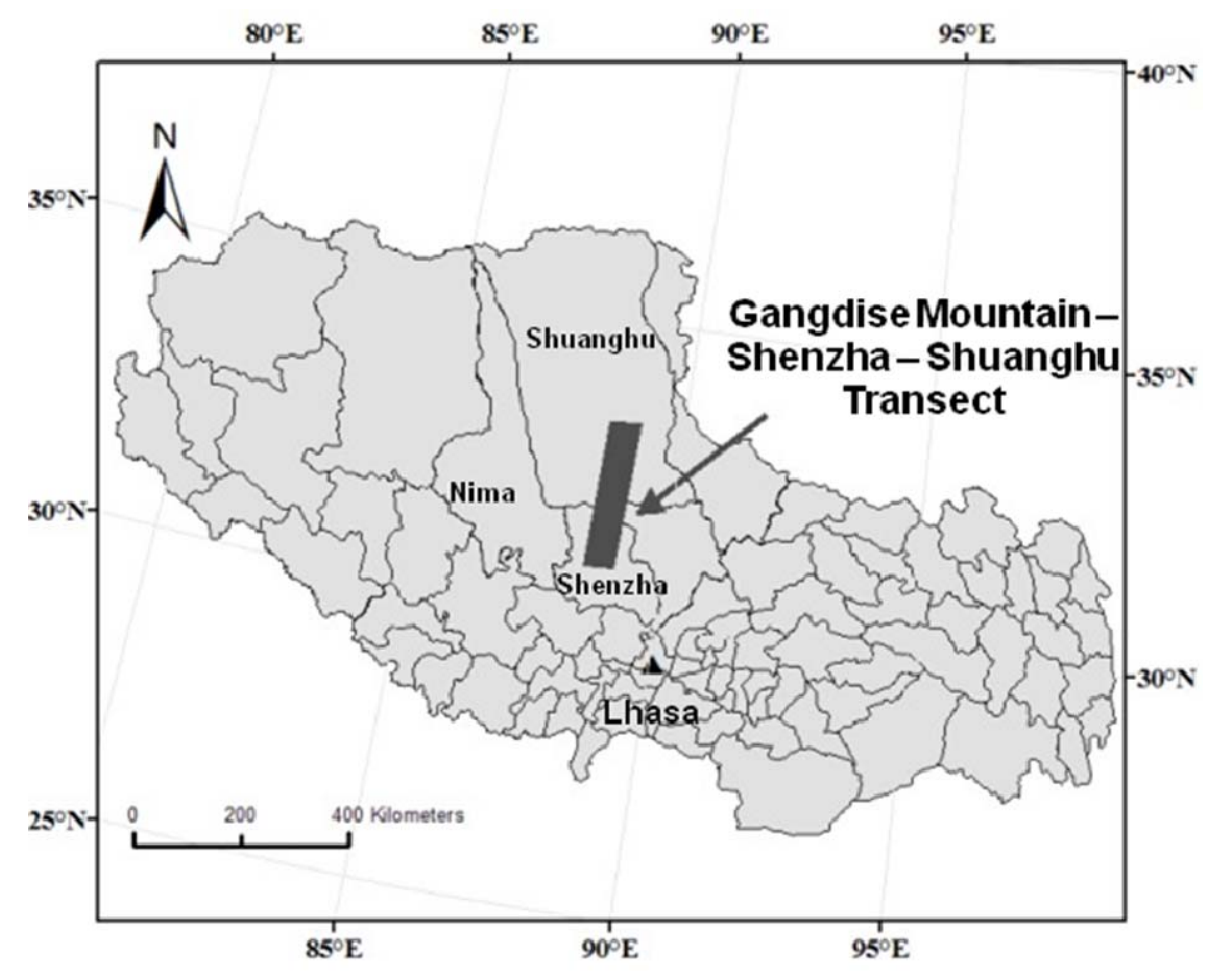

Figure 1 The geographical location of the Gangdise Mountain-Shenzha-Shuanghu Transect in Tibet, China
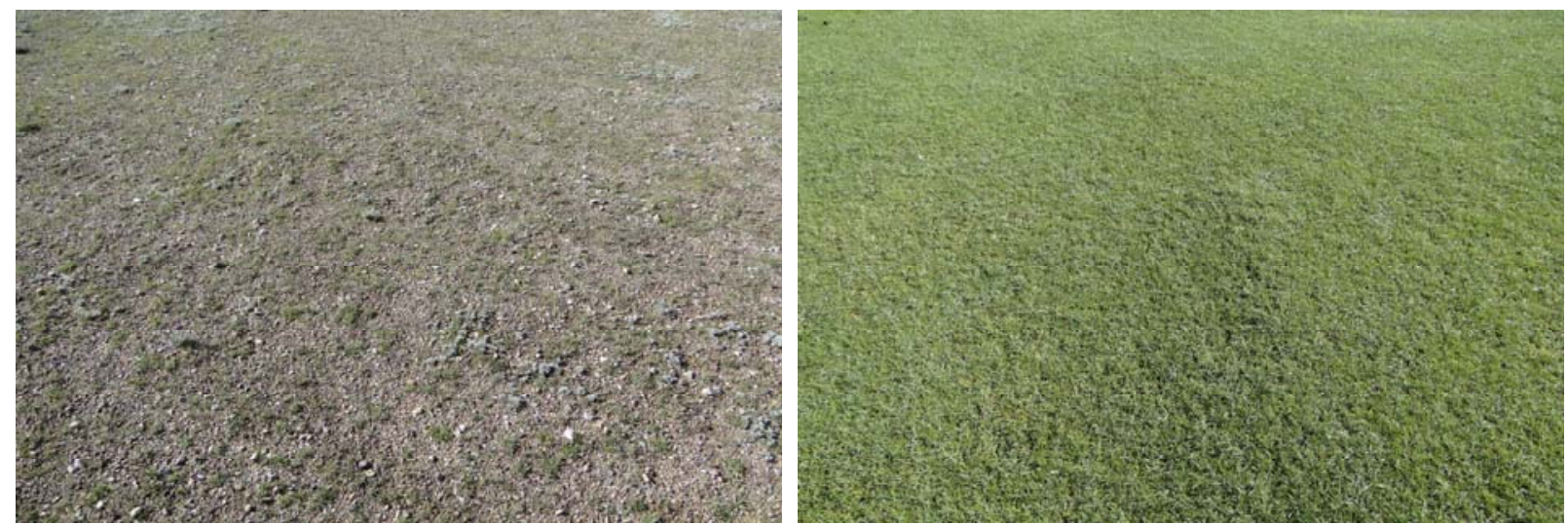

Figure 2 Alpine meadow grassland (left) and alpine steppe grassland (right) in the Gangdise Mountain-ShenzhaShuanghu Transect in Tibet, China.

Samples were collected every $5 \mathrm{~km}$. Because the sampling route was interrupted by a lake, we sampled along the coastline of the lake every $10 \mathrm{~km}$. In each sampling site, about $95 \%$ of the total root distribution was concentrated in the $0-15 \mathrm{~cm}$ soil layer while $5 \%$ of the roots were found in the 15-30 $\mathrm{cm}$ layer. Soil samples were obtained for each site and collected from two depths: $0-15 \mathrm{~cm}$ and 15-30 $\mathrm{cm}$. Forty-four samples were taken in total. For the determination of soil bulk density, soil cores (5.4 $\mathrm{cm}$ in diameter) were also taken from each layer using a stainless-steel cylinder. In addition, soil type, colour, temperature, and moisture were also recorded. The location and elevation of each site were measured using GPS (Garmin MAP6oCSX made in Garmin Ltd, <10 meters accuracy).

\subsection{Soil physical and chemical analysis}

Prior to analysis, all soil samples were airdried and then hand-sieved through a 2-mm mesh to remove roots and other debris ( $\mathrm{Li}$ et al. 2006). 
Soil bulk density was determined as the moisturecorrected (oven-dried at $105^{\circ} \mathrm{C}$ ) mass of each sample divided by the measured excavation volume (Zarin et al. 1998). SOC content was measured by potassium dichromate oxidation with external heating (Nelson et al. 1982). TN was determined by the semi-micro-Kjeldahl method. TP was determined by the sodium bicarbonate alkali digestion method and by molybdenum antimony colorimetry (Institute of Soil Academia Sinica 1978). Available $\mathrm{N}$ was determined by a micro-diffusion technique after alkaline hydrolysis (Fu et al. 2000). Available P was extracted with 0.5 mol.L-1 $\mathrm{NaHCO}_{3}$ solution ( $\mathrm{pH}$ 8.5). Soil particle-size distribution was determined using a Malvern Mastersizer 2000 particle size analyser (Worcs UK)

\subsection{Calculations of SOC, TN, and TP stocks and fractal dimension of particle size distribution (PSD)}

SOC stocks for each sample depth were calculated using the following equations:

$$
\mathrm{SOC}\left(\mathrm{g} \mathrm{m}^{-2}\right)=\mathrm{Z} \times \mathrm{BD} \times \mathrm{SOC}_{\mathrm{s}} \times 10
$$

where $\mathrm{z}$ is the thickness of each sample depth $(\mathrm{cm})$, $\mathrm{BD}$ is bulk density $\left(\mathrm{g} \mathrm{cm}^{-3}\right)$ of each sample depth and $\mathrm{SOC}_{\mathrm{s}}$ is the $\mathrm{SOC}$ concentration ( $\mathrm{g} \mathrm{C} \mathrm{kg}^{-1}$ soil) of each sample depth. The numerical value 10 is used for units exchange. TN and TP stocks $\left(\mathrm{g} \mathrm{m}^{-2}\right)$ were also computed with a similar formula.

The fractal dimension of PSD (D) was estimated using the following equation(Tyler and Wheatcraft 1992, Su et al 2004):

$$
\frac{V\left(r<R_{i}\right)}{V_{T}}=\left(\frac{R_{i}}{\lambda_{v}}\right)^{3-D}
$$

where $r$ is soil particle size, $V\left(r<R_{i}\right)$ is the cumulative volume of a particle of the ith size $r$ less than $R_{i}, V_{T}$ is the total volume, $R_{i}$ is the mean particle volume of the $i$ th size class, and $\lambda_{V}$ is the mean volume of the largest particle; the mean particle volume was taken as the arithmetic mean of the upper and lower sieve sizes, and the mean diameter of particles $<2 \mu \mathrm{m}$ was calculated as $1 \mu \mathrm{m}$.

\subsection{Data analysis}

Classical statistical descriptors such as minimum, maximum mean and standard deviation
(SD) were determined. An analysis of variance (ANOVA) test was performed to analyse differences between soil characteristics (SOC, TN, TP, AN, AP, sand, silt and clay content) and SOC/TN and SOC/TP ratios between the two sample depths within grassland types or in the entire transect as well as between the two types of grassland. Significant differences for all statistical tests were determined at the level of $\mathrm{P} \leq 0.05$. Correlation analysis was used to determine the relationship between edaphic factors (sand, silt and clay) and SOC content in the different soil layers. A simple regression analysis was applied to establish relationships between the fractal dimension and soil characteristics (sand, silt, clay, SOC, TN and TP contents). All statistical analyses were performed using the SPSS ver. 17.0 software package (SPSS Inc. USA).

\section{Results and Discussion}

\subsection{Spatial changes in SOC, $N$ and $P$}

As can be seen from Table 1, mean total SOC, $\mathrm{TN}$ and TP stocks in the upper $30 \mathrm{~cm}$ of soil varied from $8.54 \mathrm{~kg} \mathrm{C} \mathrm{m}^{-2}, 0.65 \mathrm{~kg} \mathrm{~N} \mathrm{~m}^{-2}$ and $0.24 \mathrm{~kg} \mathrm{P} \mathrm{m}^{-2}$, respectively, in alpine meadow, to $4.18 \mathrm{~kg} \mathrm{C} \mathrm{m}^{-2}$, $0.40 \mathrm{~kg} \mathrm{~N} \mathrm{~m}^{-2}$ and $0.19 \mathrm{~kg} \mathrm{P} \mathrm{m}^{-2}$, respectively, in alpine steppe areas. SOC, TN, TP, AN and AP stocks in the upper $30 \mathrm{~cm}$ of soil in the alpine meadow are significantly higher $(\mathrm{P}<0.05)$ than those in the alpine steppe. Compared to previous

Table 1 Statistical characteristics of SOC, total N, total $\mathrm{P}$, available $\mathrm{N}$ and available $\mathrm{P}$ in alpine meadow and alpine steppe areas along the Gangdise MountainShenzha-Shuanghu Transect in Tibet, China

\begin{tabular}{|l|l|l|l|l|l|}
\hline $\begin{array}{l}\text { Tested items } \\
\text { Alpine meadow }\end{array}$ & Min. & Max. & Mean S.D. & CV \\
\hline SOC $\left(\mathrm{kg} \cdot \mathrm{m}^{-2}\right)$ & 5.69 & 12.40 & 8.54 & 2.48 & 0.29 \\
\hline Total N $\left(\mathrm{kg} \cdot \mathrm{m}^{-2}\right)$ & 0.47 & 0.93 & 0.65 & 0.17 & 0.26 \\
\hline Total P $\left(\mathrm{kg} \cdot \mathrm{m}^{-2}\right)$ & 0.21 & 0.30 & 0.24 & 0.03 & 0.13 \\
\hline Available N (g.m $\left.{ }^{-2}\right)$ & 26.10 & 70.16 & 45.12 & 14.25 & 0.32 \\
\hline Available P (g.m-2) & 1.81 & 2.93 & 2.24 & 0.46 & 0.21 \\
\hline Alpine steppe & & & & & \\
\hline SOC $\left(\mathrm{kg} \cdot \mathrm{m}^{-2}\right)$ & 0.80 & 7.60 & 4.18 & 1.68 & 0.41 \\
\hline Total N $\left(\mathrm{kg} \cdot \mathrm{m}^{-2}\right)$ & 0.11 & 0.82 & 0.40 & 0.14 & 0.35 \\
\hline Total P $\left(\mathrm{kg} \cdot \mathrm{m}^{-2}\right)$ & 0.14 & 0.25 & 0.19 & 0.025 & 0.14 \\
\hline Available N (g.m $\left.{ }^{-2}\right)$ & 9.71 & 52.22 & 23.47 & 8.51 & 0.36 \\
\hline Available P $\left(\mathrm{g} \cdot \mathrm{m}^{-2}\right)$ & 1.36 & 3.32 & 1.99 & 0.45 & 0.23 \\
\hline
\end{tabular}


results, we found lower SOC stock in two alpine grasslands (Wang et al. 2002; Tao et al. 2007). The coefficient of variation (CV) was used to qualitatively describe the magnitude of spatial variability as weak when $\mathrm{CV}<0.1$, moderate if 0.1 $<\mathrm{CV}<1$, and strong when CV $>1$ (Yang et al. 2011). The CV of both grassland types can be arranged in the order $\mathrm{SOC}>\mathrm{AN}>\mathrm{TN}>\mathrm{AP}>\mathrm{TP}$, and all are moderately variable. SOC exhibits the largest spatial variability because many factors, such as land management(Conant et al. 2001), precipitation, air temperature, and grassland type (Jobbágy and Jackson 2000), can influence SOC content. The CV of TP was smaller because TP content is largely determined by the soil parent material (Liu et al. 2005).

A few authors proved that root distributions affect the vertical placement of $\mathrm{C}$ in the soil, and above- and below-ground allocation affects the relative amount of $\mathrm{C}$ that eventually falls to the soil surface from shoots (Jobbágy and Jackson 2000). However, no similar results were observed in the current study. The percentage of SOC in the top 15 $\mathrm{cm}$ averages $54.7 \%$ and $52.0 \%$ for alpine meadow and alpine steppe environments, respectively. SOC content is slightly higher in the upper layer, but the difference is not significant in soil depth. ANOVA showed no significant difference in TN, TP and AN contents between top soil $(0-15 \mathrm{~cm})$ and sub-top soil $(15-30 \mathrm{~cm})$. Available P content is significantly higher in the upper $15 \mathrm{~cm}$ of soil than in the 15-30 $\mathrm{cm}$ soil $(\mathrm{P}<0.05)$. Surface enrichment of $\mathrm{P}$ may be due to return of residual organic matter to soil (Jobbágy and Jackson 2001).

Figure 3 shows that SOC and TN distribution are similar, while TP concentration varies with latitude along the GSST. On a larger scale, SOC and TN stocks decrease from southern to northern regions corresponding to precipitation patterns. However, the trends in total SOC, TN and TP stocks in the upper $30 \mathrm{~cm}$ of soil along the latitudinal transect did not always follow these patterns. For instance, despite decreasing precipitation along the transect, SOC and TN concentrations increased in the latitude range from $30.92^{\circ} \mathrm{N}$ to $31.42^{\circ} \mathrm{N}$ and $31.87^{\circ} \mathrm{N}$ to $32.48^{\circ} \mathrm{N}$, respectively. The unusual trend in $\mathrm{SOC}$ and $\mathrm{TN}$ stocks in the upper $30 \mathrm{~cm}$ of soil were in direct proportion to the amount of precipitation and inversely proportional to the mean annual temperature (Post et al. 1982; Trumbore et al. 1996). SOC and TN stocks increased from $30.92^{\circ} \mathrm{N}$ to $31.42^{\circ} \mathrm{N}$ latitude, but precipitation did not change significantly in this region; this trend is likely due to the joint interactions between precipitation, temperature and amount of primary production in controlling soil $\mathrm{C}$ and $\mathrm{TN}$ storage. However, increasing SOC and TN stocks from $31.87^{\circ} \mathrm{N}$ to $32.48^{\circ} \mathrm{N}$ latitude may reflect the role of precipitation in controlling SOC and TN storage. The primary mineral source of $\mathrm{P}$ in most soils is apatite in the parent material. Organisms and plant roots take up $\mathrm{P}$ from the surrounding soil and then return it to the soil in the form of organic $P$ (Parton et al. 1988). Therefore, soil organic $P$ increased with high soil organic matter content. Soil TP stocks are more affected by parent material and human disturbance, but northern Tibet is sparsely populated, so $\mathrm{P}$ distribution along the latitude gradient may reflect the joint interaction between soil parent material and organic matter. In addition, the lake located in the study area maybe have potential effects on the distribution of SOC, TN, TP. More studies will be needed in future.

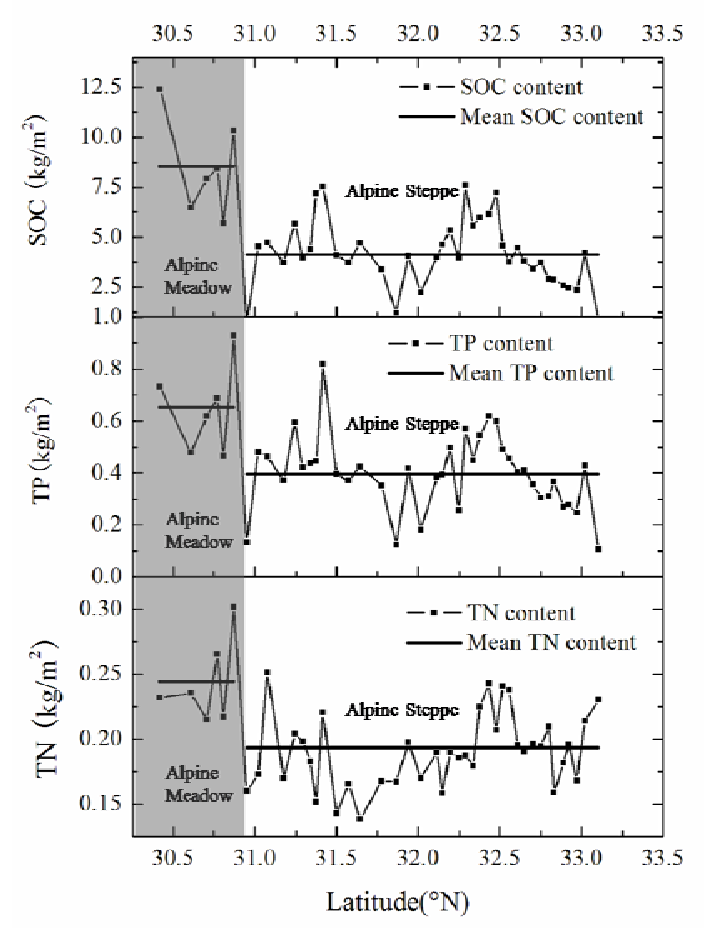

Figure 3 The distribution of SOC, TN and TP content in the upper $30 \mathrm{~cm}$ of soil along the latitude gradient of the Gangdise Mountain-Shenzha-Shuanghu Transect in Tibet, China (Dark grey shows the SOC, TN and TP variations in alpine meadow, and light gray shows the unusual distribution of SOC and TN) 


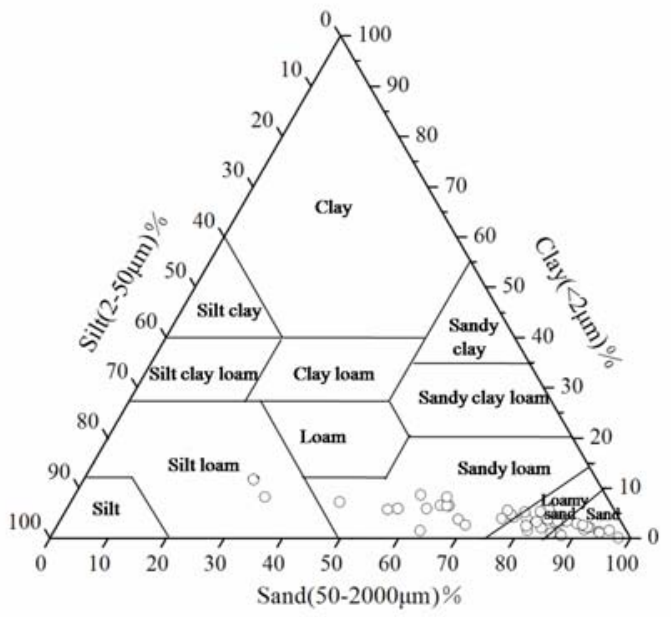

(A)

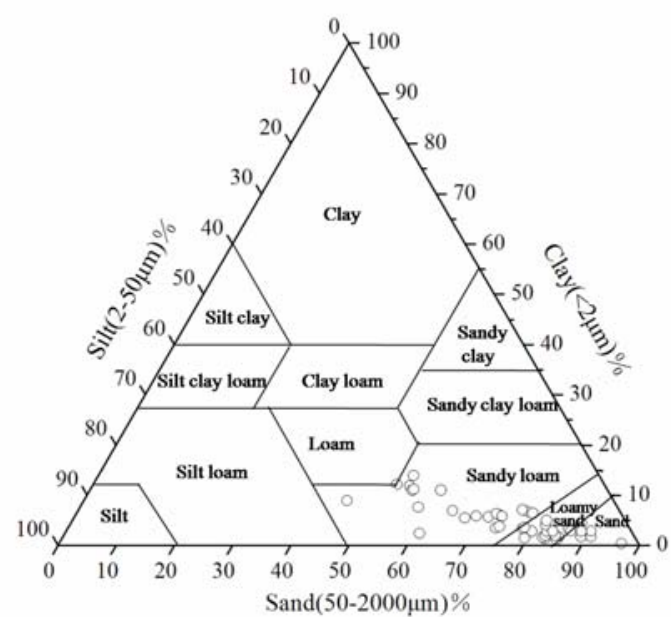

(B)

Figure 4 The distribution of 44 soil samples $(A: 0-15 \mathrm{~cm}$; B: 15-30 cm) within the USDA-SCS soil textural triangle.

\subsection{Particle size spatial distribution}

In Figure 4, soil sample texture is shown in the USDA soil texture triangle. There are four kinds of texture in the topsoil $(0-15 \mathrm{~cm})$ samples from the Gangdise Mountain-Shenzha-Shuanghu Transect. One is medium-textured (silt loam) and the others are coarse-textured (sand, loamy sand, and sandy loamy). The dominant soil textures are sand (31.81\%), loamy sand (36.36\%) and sandy loam (27.27\%). Statistical results from soil depth showed the mean sand, silt, and clay contents are $77.65 \%$, $18.2 \%$, and $4.15 \%$ in the top soil and $75.47 \%$, $19.55 \%$, and $4.98 \%$ in the sub-top soil, respectively (Table 2). This pattern indicated that sand constitutes the largest proportion of soil in this region. Wind erosion sorts the soil material, with removal of fine particles (clays and silts) and leaving behind a more coarse-texture soil (Lobe et al. 2001). The CV of both soil depths can be placed in the order clay $>$ silt $>$ sand, and all are moderately variable. Clay and silt variability are higher than that of sand because wind erosion is prevalent along the transect, and fine-grained particles are easily moved by wind (Wang et al. 2010). A one-way analysis of variance showed no significant differences between sand, silt and clay contents between sample depths and grassland types $(\mathrm{P}<0.05)$.

Table 3 shows the correlation between SOC content in the different soil layers with soil
Table 2 Statistical features for sand, silt, clay and D of two soil layers along the Gandise Mountain - Shenzha - Shuanghu Transect in Tibet, China

\begin{tabular}{|l|l|l|l|l|l|}
\hline & Min. & Max. & Mean & S.D. & CV \\
\hline O-15 cm & & & & & \\
\hline Sand (\%) & 36.12 & 97.82 & 77.65 & 13.84 & 0.18 \\
\hline Silt (\%) & 2.09 & 50.96 & 18.20 & 11.30 & 0.62 \\
\hline Clay (\%) & 0.09 & 14.44 & 4.15 & 2.85 & 0.69 \\
\hline D & 1.98 & 2.74 & 2.49 & 0.13 & 0.05 \\
\hline 15-30 cm & & & & & \\
Sand (\%) & 45.27 & 96.74 & 75.47 & 12.45 & 0.16 \\
\hline Silt (\%) & 2.88 & 45.78 & 19.55 & 9.71 & 0.50 \\
Clay (\%) & 0.38 & 13.89 & 4.98 & 3.42 & 0.69 \\
\hline D & 2.16 & 2.72 & 2.53 & 0.11 & 0.04 \\
\hline
\end{tabular}

Note: "D" means "The fractal dimension of particle size distribution".

Table 3 Correlative analysis between edaphic factors and SOC content in different soil layers

\begin{tabular}{|l|l|l|}
\hline Soil texture & $0-15 \mathrm{~cm}$ & $15-30 \mathrm{~cm}$ \\
\hline Sand & $-0.359^{*}$ & 0.235 \\
\hline Silt & $0.406^{* *}$ & -0.131 \\
\hline Clay & 0.132 & -0.147 \\
\hline D & 0.227 & 0.030 \\
\hline Total N & $0.869^{* *}$ & $0.875^{* *}$ \\
\hline Total P & $0.42^{* *}$ & $0.448^{* *}$ \\
\hline Available N & $0.846^{* *}$ & $0.841^{* *}$ \\
\hline Available P & $0.371^{*}$ & 0.240 \\
\hline
\end{tabular}

Notes: * indicates significant level at $\mathrm{P}<0.05$; ** indicates significant level at $\mathrm{P}<0.01$.

properties. SOC content in the upper $15 \mathrm{~cm}$ of soil showed a significant negative correlation with sand content and an extremely significant positive correlation with silt content, which shows that silt can contribute to SOC deposition. Previous studies 
have shown that clay content has a significant positive correlation with SOC content in grassland soil (Burke et al. 1989; Nichols 1984; Tian et al. 2008). This difference can be explained by the alpine ecosystem being dominated by sandy and silty compositions.
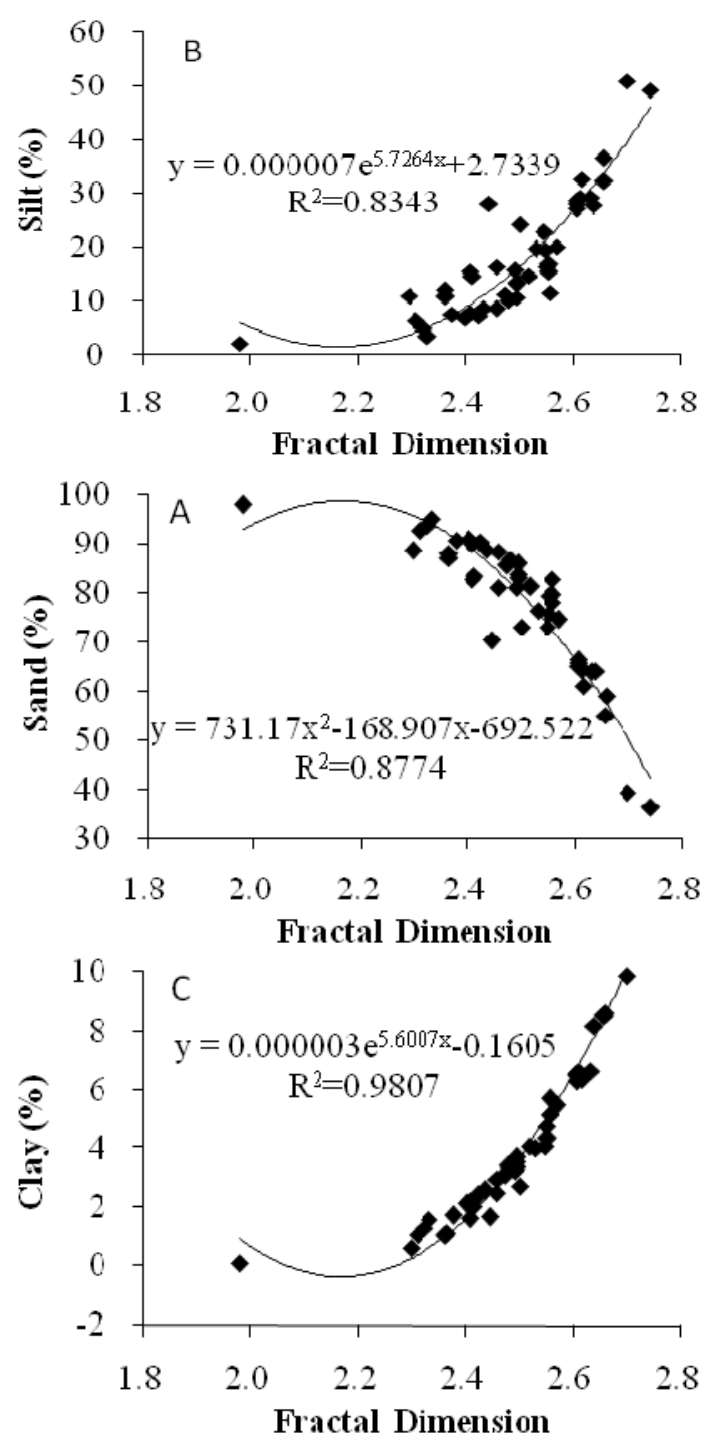

Figure 5 Relationship between fractal dimension of PSD and sand (A), silt (B) and clay (C) content

As seen in Table 2, the lowest value of $\mathrm{D}$ (1.98 for the top $15 \mathrm{~cm}$ of soil and 2.16 for $15-30 \mathrm{~cm}$ soil) coincides with the lowest clay and silt content (2.18 \% and 3.26\%, respectively) but highest sand contents (97.82\% and $96.74 \%$, respectively). The highest D values (2.74 for the top $15 \mathrm{~cm}$ of soil and 2.72 for $15-30 \mathrm{~cm}$ soil) coincides with the largest combined clay and silt content $(63.88 \%$ and $45.77 \%$, respectively) and the lowest sand content
(36.12\% and 54.23\%, respectively). Results from regression analysis indicate that $\mathrm{D}$ values are negatively correlated to sand content and positively correlated with the silt and clay contents. The relationship between $\mathrm{D}$ values and soil texture are expressed by sigmoid curves (Figure 5). Other authors also reported that sigmoid regression models can describe this relationship more effectively than a simple linear model (Wang et al. 2010; Zhao et al. 2009).

\subsection{Relationship between SOC and N, P}

SOC in the alpine steppe area is about 50\% lower than that in the alpine meadow regions, while TN levels in the alpine steppe are approximately $38 \%$ lower than those in alpine meadows (Table 1). Regression analysis indicated that SOC increased with TN and TP (Figure 6).
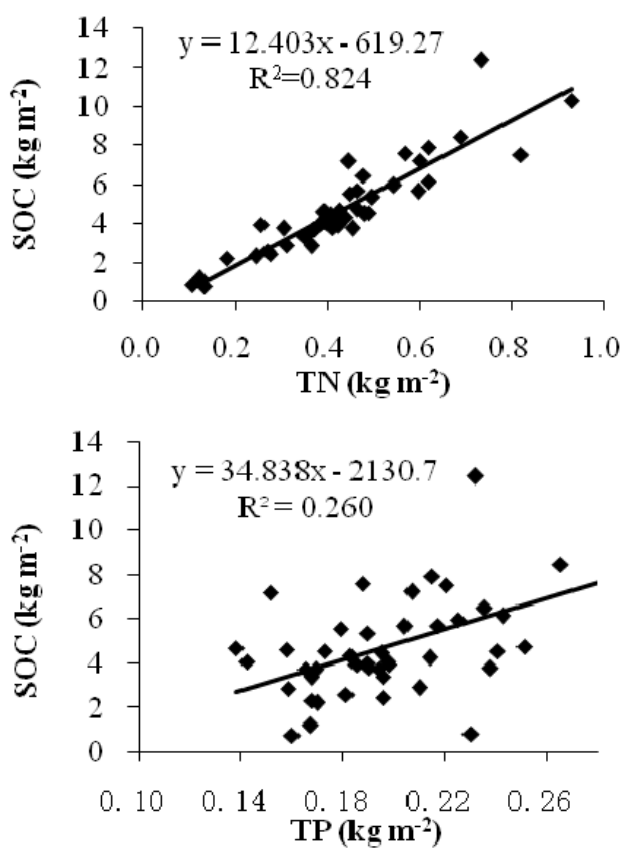

Figure 6 The relationship between SOC and TN (upper) and TP (lower) content along the Gangdise Mountain - Shenzha - Shuanghu Transect in Tibet, China

There is a significant positive correlation between SOC and TN along the latitude gradient $\left(R^{2}=0.824, P<0.05\right)$. SOC and TP also are positively correlated in the studied soils $\left(R^{2}=\right.$ 0.260; $P<0.05)$. Linear equations provides good fits for SOC and TN and TP in $0-30 \mathrm{~cm}$ soil layers, with standardised regression equations as follows : 
$\mathrm{SOC}=12.403 \mathrm{TN}-0.619$ and $\mathrm{SOC}=34.837 \mathrm{TP}-$ 2.131 .

In this study, the linear models suggest that TN is the most important parameter and explains $82.45 \%$ of SOC variation. However, the influence of nutrient availability on SOC concentration is still controversial. With elevating atmospheric carbon dioxide $\left(\mathrm{CO}_{2}\right)$, SOC sequestration is constrained by nutrient availability (Luo et al. 2004; Su \& Zhao 2002; van Groenigen et al. 2006). Other studies have shown that allocation to roots is reduced when nutrient availability is high (Craine et al. 2002). Concomitantly, low root activity can result in a reduction in $\mathrm{CO}_{2}$ effluxes (Keith et al. 1997). Although microbial activity is the main factor influencing carbon stored in substrates, evidence from other studies suggests that increased nutrient availability results in higher respiration rates (McCulley et al. 2004; Adair et al. 2011).

\section{Conclusions}

This study revealed a set of data that quantified spatial changes of soil properties along an alpine grassland transect on the northern Tibetan Plateau. Fractal approaches and statistic analysis were applied to detect relationship between soil texture and carbon, nitrogen, phosphorus the in different soil depth. We found that the overall SOC, TN and TP contents are relatively low with a south to north decreasing spatial distribution pattern. Grassland type is a main factor influencing SOC and TN content, while TP is more affected by parental materials. Vertical distribution of SOC and TN were similar, with no differences found in soil depth, while TP content in the top $15 \mathrm{~cm}$ of soil is significantly higher than that in the sub-top soil. SOC content is correlated negatively with sand content and extremely positively correlated with silt content, while no significant correlation with clay content. The application of the fractal method to describe soil texture, soil dynamics, and physical processes within the soil allows for a better understanding of the performance of the soil systems under different grazing intensities. Our study also provides an interesting contribution to the global data pool on soil carbon stocks due to limited knowledge in high altitude regions.

\section{Acknowledgements}

This study was supported by the Western Action Plan Project of the Chinese Academy of Sciences (Grant No. KZCX2-XB3-08), the Strategic Pilot Science and Technology Projects of Chinese Academy of Sciences (Grant No. XDBo3030505) and the One Hundred Young Persons Project of the Institute of Mountain Hazards and Environment (Grant No. SDSQB-2010-02).

\section{References}

Adair EC, Reich PB, Trost JJ et al. (2011) Elevated $\mathrm{CO}_{2}$ stimulates grassland soil respiration by increasing carbon inputs rather than by enhancing soil moisture. Global Change Biology 17: 3546-3563. DOI: 10.1111/j.1365-2486.2011.02484.

Bai YF, Wu JG, Xing Q, et al. (2008) Primary production and rain use efficiency across a precipitation gradient on the Mongolia plateau. Ecology 89(8):2140-2153. DOI: 10.1890/ 07-0992.1

Batlle-Bayer L, Batjes NH and Bindraban PS (2010) Changes in organic carbon stocks upon land use conversion in the Brazilian Cerrado: A review. Agriculture Ecosystems Environment 137(12): 47-58. DOI:10.1016/j.agee.2010.02.003

Burke I, Yonker C, Parton W, et al. (1989) Texture, climate, and cultivation effects on soil organic matter content in US grassland soils. Soil Science Society of America Journal 53(3):800-805. DOI:10.2136/sssaj1989.0361599500530003 0029x

Conant RT, Paustian K and Elliott ET (2001) Grassland management and conversion into grassland: effects on soil carbon. Ecological Applications 11(2): 343-355. DOI: 10.1890/1051-0761(2001)011[0343:GMACIG]2.0.CO;2

Craine JM, Tilman D, Wedin D, et al. (2002) Functional traits, productivity and effects on nitrogen cycling of 33 grassland species. Functional Ecology 16(5): 563-574. DOI: 10.1046/ j.1365-2435.2002.00660.x

Dijkstra FA, Hobbie SE, Knops JMH, et al. (2004) Nitrogen deposition and plant species interact to influence soil carbon stabilization. Ecology Letters 7: 1192-1198. DOI: 10.1111/ j.1461-0248.2004.00679.x

$\mathrm{Fu}$ BJ, Chen LD, Ma HF, et al. (2000) The relationships between land use and soil conditions in the hilly area of the loess plateau in northern Shaanxi, China. Catena 39(1):69-78. DOI: 10.1016/So341-8162(99)ooo84-3,

Gao QZ, Li Y, Wan YF, et al. (2009) Significant Achievements in Protection and Restoration of Alpine Grassland Ecosystem in Northern Tibet, China. Restoration Ecology 17(3): 320-323. DOI: 10.1111/j.1526-100X.2009.00527.x 
Gao QZ, Li Y, Wan YF, et al. (2009) Dynamics of alpine grassland NPP and its response to climate change in Northern Tibet. Climatic Change 97: 515-528. DOI: $10.1007 / \mathrm{s} 10584-$ oo9-9617-Z

Hamdan R, El-Rifai HM, Cheesman AW, et al. (2012) Linking Phosphorus Sequestration to Carbon Humification in Wetland Soils by $\mathrm{P}-31$ and C-13 NMR Spectroscopy. Environmental Science \& Technology 46: 4775-4782. DOI: 10.1021/es204072k

Heimann M and Reichstein M (2008) Terrestrial ecosystem carbon dynamics and climate feedbacks. Nature 451:289-292. DOI: $10.1038 /$ natureo6591

Hobbie SE (2008) Nitrogen effects on decomposition: A fiveyear experiment in eight temperate sites. Ecology 89: 26332644. DOI: 10.1890/07-1119.1

Jobbágy EG and Jackson RB (2000) The vertical distribution of soil organic carbon and its relation to climate and vegetation. Ecological Applications 10: 423-436. DOI: 10.1890/10510761(2000)010[0423:TVDOSO]2.0.CO;2

Jobbágy EG and Jackson RB (2001) The distribution of soil nutrients with depth: global patterns and the imprint of plants. Biogeochemistry 53:51-77. DOI: 10.1023/A:10107607 20215

Johnson D, Vachon J, Britton AJ, et al. (2011) Drought alters carbon fluxes in alpine snowbed ecosystems through contrasting impacts on graminoids and forbs. New Phytologist 190: 740-749. DOI: 10.1111/j.1469-8137.2010. 03613.x

Keith H, Jacobsen K and Raison R (1997) Effects of soil phosphorus availability, temperature and moisture on soil respiration in Eucalyptus pauciflora forest. Plant Soil 190: 127-141. DOI: 10.1023/A:1004279300622

Li MS (2000) Rational exploitation of grassland resources in the Northern Xizang Plateau. Journal of nature resources 15(4):335-339. (In Chinese) DOI: 10.3321/j.issn:1000-3037. 2000.04.006

Li YQ, Zhao HL, Zhao XY, et al. (2006) Biomass Energy, Carbon and Nitrogen Stores in Different Habitats along a Desertification Gradient in the Semiarid Horqin Sandy Land. Arid Land Research and Management 20(1):43-60. DOI: $10.1080 / 15324980500369285$

Liptzin D and Silver WL (2009) Effects of carbon additions on iron reduction and phosphorus availability in a humid tropical forest soil. Soil Biology \& Biochemistry 41: 1696-1702. DOI: 10.1016/j.soilbio.2009.05.013

Liu SQ, Gao LL, Pu YL, et al. (2005) Status of Soil P and K Nutrient and Their Influencing Factors in Tibet. Journal of Soil Water Conservation 19(1):75-78. (In Chinese) DOI: 10.3321/j.issn:1009-2242.2005.01.019

Liu X, Ma Y and Laba YZ (2003) Climatic Regionalization of the animal husbandry of Nagqu region. Beijing: Meteorological Press,. (In Chinese)

Lobe I, Amelung W and Du Preez C (2001) Losses of carbon and nitrogen with prolonged arable cropping from sandy soils of the South African Highveld. European Journal of Soil Science 52(1): 93-101. DOI: 10.1046/j.1365-2389.2001.to1-1-00362.x

$\mathrm{Lu}$ FM, Lu XT, Liu W, et al. (2011) Carbon and nitrogen storage in plant and soil as related to nitrogen and water amendment in a temperate steppe of northern China. Biology and Fertility of Soils 47(2): 187-196. DOI: 10.1046/j.1365-2389.2001.to1-100362.x

Luo Y, Su B, Currie WS, et al. (2004) Progressive nitrogen limitation of ecosystem responses to rising atmospheric carbon dioxide. Bioscience 54: 731-739. DOI: 10.1641/00063568(2004)054[0731:PNLOER]2.0.CO;2

Mack MC, Schuur EAG, Bret-Harte MS, et al. (2004) Ecosystem carbon storage in arctic tundra reduced by long-term nutrient fertilization. Nature 431: 440-443. DOI: $10.1038 /$ natureo2887

Magill AH, Aber JD, Hendricks JJ, et al. (1997) Biogeochemical response of forest ecosystems to simulated chronic nitrogen deposition. Ecological Applications 7: 402-415. DOI: 10.1890/ 1051-0761(1997)007[0402:BROFET]2.0.CO;2
McDowell RW and Sharpley AN (2003) The effects of soil carbon on phosphorus and sediment loss from soil trays by overland flow. Journal of Environmental Quality 32: 207-214. DOI: $10.2134 /$ jeq2003.2070

McCulley RL, Archer SR, Boutton TW, et al. (2004) Soil respiration and nutrient cycling in wooded communities developing in grassland. Ecology 85: 2804-2817. DOI: 10.1890/03-0645

Nelson DW, Sommers LE(1982) Total Carbon, Organic Carbon, and Organic Matter. Methods of Soil Analysis :539-579. DOI: 10.2134/agronmonogr9.2.2ed.c29

Ni J, Zhang XS (2000) Climate variability, ecological gradient and the Northeast China Transect (NECT). Journal of Arid Environments 46(3): 313-325. DOI: 10.1006/jare.2000.0667

Nichols J (1984) Relation of Organic Carbon to Soil Properties and Climate in the Southern Great Plains. Soil Science Society of America Journal 48(6): 1382-1384. DOI: 10.2136/sssa j1984.03615995004800060037x

Parton W, Schimel D, Ojima D, et al. (1994) A general model for soil organic matter dynamics: sensitivity to litter chemistry, texture and management. Soil Science Society of America 39: 147-167. DOI: 10.2136/sssaspecpub39.c9

Parton WJ, Stewart JWB and Cole CV (1988) Dynamics of C, N, $P$ and $S$ in grassland soils: a model. Biogeochemistry 5(1): 109-131. DOI: $10.1007 / \mathrm{BF} 02180320$

Piao SL, Ciais P, Lomas M, et al. (2011) Contribution of climate change and rising $\mathrm{CO}_{2}$ to terrestrial carbon balance in East Asia: A multi-model analysis. Global Planetary Change 75: 133-142. DOI: 10.1016/j.gloplacha.2010.10.014,

Post WM, Emanuel WR, Zinke PJ, et al. (1982) Soil carbon pools and world life zones. Nature 298: 156-159. DOI: 10.1038/298156ao

Preger AC, Kosters R, Du Preez CC, et al. (2010) Carbon sequestration in secondary pasture soils: a chronosequence study in the South African Highveld. European Journal of Soil Science 61(4): 551-562. DOI: $10.1111 / \mathrm{j} .1365-2389.2010 .01248$. $\mathrm{x}$

Saggar S, Hedley CB, Giddens KM. et al. (2000) Influence of soil phosphorus status and nitrogen addition on carbon mineralization from C-14-labelled glucose in pasture soils. Biology and Fertility of Soils 32(3): 209-216. DOI: 10.1007/ so03740000237

$\mathrm{Su}$ YZ and Zhao HL (2002) Advances in Researches on Soil Organic Carbon Storages, Affecting Factors and Its Environmental Effects. Journal of Desert Research 22(3):220-229. (In Chinese) DOI: 10.3321/j.issn:1000-694X. 2002.03.004

Su YZ, Zhao HL, Zhao WZ, et al. (2004) Fractal features of soil particle size distribution and the implication for indicating desertification. Geoderma 122(1): 43-49. DOI: 10.1016/ j.geoderma.2003.12.003

Tao Z, Shen CD, Gao QZ, et al. (2007) Soil organic carbon storage and soil $\mathrm{CO}_{2}$ flux in the alpine meadow ecosystem. Science in China.Science in China Series D:Earth Sciences 5O(7):1103-1114. DOI: 10.1007/s11430-007-0055-3

Tian Y, Ouyang H, Song M, et al. (2008) Distribution characteristics and influencing factors of soil organic carbon in alpine ecosystems on the Tibetan Plateau transect, China. Frontiers of Agriculture in China 2(4): 404-409. DOI: 10.1007/s11703-008-0050-2

Trumbore SE, Chadwick OA and Amundson R (1996) Rapid exchange between soil carbon and atmospheric carbon dioxide driven by temperature change. Science 272(5260): 393-396. DOI: 10.1126/science.272.5260.393

Tyler SW and Wheatcraft SW (1992) Fractal scaling of soil particle-size distributions: analysis and limitations. Soil Science Society of America Journal 56(2):362-369. DOI: 10.2136/sssaj1992.03615995005600020005x

Van Groenigen KJ, Six J, Hungate BA, et al. (2006) Element interactions limit soil carbon storage. Proceedings of the National Academy of Sciences of the United States of America 103(17): 6571-6574. DOI: 10.1073/pnas.0509038103 
Wamelink GWW,Van Dobben HF, Mol-Dijkstra JP, et al. (2009) Effect of nitrogen deposition reduction on biodiversity and carbon sequestration. Forest Ecology and Management 258(8): 1774-1779. DOI: 10.1016/j.foreco.2008.10.024

Wang GX, Qian J, Cheng GD, et al. (2002) Soil organic carbon pool of grassland soils on the Qinghai-Tibetan Plateau and its global implication. The Science of the Total Environment 291(1-3): 207-217. DOI: 10.1016/So048-9697(01)01100-7

Wang S and Zhou C (1999) Estimating soil carbon reservoir of terrestrial ecosystem in China. Geographical Research 18(4): 349-356. (In Chinese) DOI: 10.3321/j.issn:1000-0585.1999. 04.003

Wang SQ, Liu JY, Zhang C, et al. (2011) Effects of afforestation on soil carbon turnover in China's subtropical region. Journal of Geographical Sciences 21(1): 118-134. DOI: 10.1007/ s11442-011-0833-x

Wang XD, Yan Y and Cao YZ (2012) Impact of historic grazing on steppe soils on the northern Tibetan Plateau. Plant Soil 354: 173-183. DOI: $10.1007 /$ s11104-011-1053-y

Wang YQ, Shao MA and Gao L (2010) Spatial Variability of Soil Particle Size Distribution and Fractal Features in Water-Wind Erosion Crisscross Region on the Loess Plateau of China. Soil Science 175(2): 579-585. DOI: 10.1097/SS.obo13e3181fda413

Wilson GWT, Rice CW, Rillig MC, et al. (2009) Soil aggregation and carbon sequestration are tightly correlated with the abundance of arbuscular mycorrhizal fungi: results from longterm field experiments. Ecology Letters 12(5): 452-461. DOI: 10.1111/j.1461-0248.2009.01303.x

$\mathrm{Xu}$ XL, Liu W and Kiely G (2011) Modeling the change in soil organic carbon of grassland in response to climate change: Effects of measured versus modelled carbon pools for initializing the Rothamsted Carbon model. Agriculture, Ecosystems \& Environment 140: 372-381. DOI: 10.1016/ j.agee.2010.12.018

Yang F, Zhang GX, Yin XR, et al. (2011) Field-Scale Spatial Variation of Saline-Sodic Soil and Its Relation with Environmental Factors in Western Songnen Plain of China. International Journal of Environmental Research and Public Health 8(2):374-387. DOI: 10.3390/ijerph8020374

Yang K, Lin ED and Gao QZ (2010) Simulation of climate change impacts on grassland productivity in Northern Tibet. Chinese Journal of Ecology 29(7): 1469-1476. (In Chinese)

Yang YJ, Zhu JJ, Zhao CJ, et al. (2011). The spatial continuity study of NDVI based on Kriging and BPNN algorithm. Mathematical and Computer Modelling 54:1138-1144. DOI: 10.1016/j.mcm.2010.11.046

Zarin DJ, Johnson AH, Suzanne M (1998) Thomas. Soil organic carbon and nutrient status in old-growth montane coniferous forest watersheds, Isla Chiloé, Chile. Plant and Soil 201(2):251-258. DOI: 10.1023/A:1004375920790

Zhao P, Shao M and Zhuang J (2009) Fractal features of particle size redistributions of deposited soils on the dam farmlands. Soil Science 174(7): 403-407. DOI: 10.1097/SS.obo13e3 181aea79a 